\title{
Participation in Religious Organizations, Positive Social Capital, and Academic Success in Children
}

\author{
Sylvia D. Briscoe
}

\begin{abstract}
America's achievement gap is an unrelenting problem. The purpose of this qualitative case study was to understand how and why children who experience reduced social capital acquire academic success when given more opportunities to attain positive social capital. This investigation used a qualitative, explanatory, single-case study, with purposeful sampling to select the research participants. The results of the data included three major themes: Organizational Social Capital, Servant Leaders, and Positive Attitudes. The recommendations for further study include action research projects and qualitative studies to access grounded data from the standpoint of children living the phenomena and in settings other than churches.
\end{abstract}

Index Terms-Educational achievement gap, social networks, social capital, social isolation.

\section{DisAdVANTAGED NeIGHBORHOODS AND THE ACHIEVEMENT GAP}

Wilson [1] suggested that America's unrelenting achievement gap may be reduced when the obstacles created from socially and economically disadvantaged neighborhoods have been resolved. The obstacles experienced by individuals residing in these disadvantaged neighborhoods included lack of enthusiasm, limited educational opportunities, unreliable family situations, underemployment, increased crime, and drug and alcohol abuse [2]. He found that significant changes in the economy greatly affected children residing in inner-city America by increasing social isolation and decreasing positive social capital because of their limited access to adults whose actions and way of life positively promoted academic success in school. Increasing the levels of positive social capital in the lives of children who reside in neighborhoods that are disadvantaged socially and economically may help to alleviate the above obstacles and develop the values, skills, and goals required for academic success.

\section{SCHOOLS AND ELIMINATING THE ACHIEVEMENT GAP}

Eliminating the achievement gap has been an unattainable task for decades in America. Research has demonstrated that focusing on schools alone is part of the problem. The solution also lies in understanding how underachieving students are affected by their environments and relationships as they grow and mature. McCombs [3] shared the importance of academic investigations not only focusing

Manuscript received November 5, 2013; revised January 22, 2014.

Sylvia D. Briscoe is with the Argosy University, Philadelphia (e-mail: sylviabriscoe03@gmail.com). on education institutions, but also discovering the interpersonal connections that may alter the outlooks of isolated and underperforming students.

\section{Social CAPITAL}

In 1916, Mr. Hanifan, State Supervisor of Rural Schools, Charleston, West Virginia, published an article entitled, "The Rural School Community Center," where he wrote,

The story which follows is a concrete example of how a rural community of West Virginia in a single year actually developed social capital and then used this capital in the general improvement of its recreational, intellectual, moral and economic conditions [4].

This is the first acknowledged and published use of the term social capital. Social capital was defined as an accumulation of social interactions acquired from multiple contacts with family and community that greatly assisted the individual and the group. The article did not introduce a theory, but shared practical examples in the acquisition, accumulation, and uses of social capital in the community.

Bourdieu [5] defined social capital as social networks, which change in certain situations, to economic capital, and may also be established through holding certain positions of authority. Coleman [6] stated that social capital are the "social-structural resources" available to individuals in various forms that always possess some characteristic of a social network, and resources that empower persons within the social network. It is a resource that can significantly affect an individual's capacity to improve their life circumstances and achieve goals that may not have been possible without it.

Putnam [7] shared that social capital results in individual and group productivity that is acquired through the positive social networks in our society. He contends that a lack of positive social capital in society may result in less tolerance, cultural superiority, and increased corruption. Whereas increased social capital facilitates mutual support, cooperation, trust, and institutional proficiency. Social capital takes on two forms. Bonding social capital where individuals have a lot in common and create relationships that effect values and goals, and bridging social capital where individuals or groups do not share the same social status but create relationships that effect behaviors. Putman and Feldstein [8] reported that bridging social capital is more valuable because of its positive effects on equity and diversity in our society. According to Beyerlein and Hipp [9], bonding social capital often limits access to individuals outside of the immediate environment, whereas bridging social capital increases an individual's access to a variety of network with more opportunity for access to information and resources that will benefit them in the future. The strong 
relationships resulting from bonding or bridging social capital creates mutual trust, group identification, and educational success [10]. Lin [11] summarized the various definitions of social capital by academicians in the past as an "investment in social relations with expected return in the marketplace".

\section{CReating And Maintaining Social Capital}

Coleman shared three requirements for the creation and maintenance of social capital. They are: 1) Closure - where individuals with different characteristics exist within social networks to assist in the development of norms, and create connections where individuals expect others, within the network, to reinforce the expectancy and responsibilities of members within the network. 2) Stability - is imperative particularly within informal organizations therefore informal organizations must assign individuals to positions within the structure to create some form of stability. 3) Ideology - that develops responsibility in individuals to act in ways that do not benefit them, but furthers the interest of something else.

\section{Religious Organizations AND Social CAPITAL}

Coleman shared six forms of social capital that may be available in an individual's life as a resource, and the church is one scenario that includes all six forms. The six forms of social capital are:

1) Responsibility and Anticipation where mutual trust is significant in the transference of social capital from one to another and the rationale for individuals acting out of responsibility without the anticipation of return for these actions.

2) Information because without it an individual may not know or understand the various options available for them upon which to act.

3) Standards and Operational Support that is reinforced by the group and encourages individuals to work unselfishly for the common good of the community.

4) Relationships with Authority Figures are the transference of personal power and control to a charismatic leader who ultimately converts individual power to a shared power where social capital is used to collectively solve life's difficulties.

5) "Appropriable" Organizations that are not traditionally considered for particular purpose of the transference of social capital but are often a great resource for social capital.

6) "Intentional" Organizations are organizations formed for the sole purpose of creating social capital and often function on a totally voluntary basis for the common good of all.

According to Putnam, America is responsible for creating more new religions than any other society. Therefore, religious organizations in America must realize their ability to energize the connections within to create social capital that will positively affects its membership and the greater community [12].

\section{RELIGIOUS ORGANIZATIONS, AFRICAN AMERICANS AND SOCIAL CAPITAL}

Harris [13] found that the social capital found in religious organizations is more beneficial to African-Americans than any other ethnic group. This may be a result of the historical role religious organizations have played in the social and political development of the lives of African-Americans and the horizontal power structure of most African-American religious organizations. According to Coleman [14], the horizontal relationships are the only relationships that facilitate the creation of social capital. When power is topdown, vertical, certain community problems are often viewed as unimportant to the larger organization. Gaines [15] proclaimed the African-American church as a prolific source of social, human and economic capital that has positively influence members of its community over the years. Taylor and Chatters [16] stated that for AfricanAmericans, religious organizations have been and still are an important source of emotional support that occurs through the give-and-take of information, opinions, and shared sentiments of the membership.

\section{RESEARCH QUESTION AND HYPOTHESIS}

The research question ask "How and why does participation in activities at religious organizations increase the positive social capital required for the academic success of African-American children, ages 10-12, who experience decreased levels of positive neighborhood social capital?" The hypotheses are:

1) African-American children, ages 10-12, who participate in activities in religious organizations and increase their opportunities to acquire positive social capital, experience academic success.

2) African-American children, ages 10-12, who participate in activities in religious organizations and increase their opportunities to acquire positive social capital through interactions with adults, as church leadership, experience academic success.

3) African-American children, ages 10-12, who participate in activities in religious organizations and increase their opportunities to acquire positive social capital through amplified opportunities to develop positive attitudes about education and academic success.

\section{Methodology}

The research design was a bounded, explanatory, singlecase study that explored the phenomenon through different perspectives to discover all aspects of the investigation topic [17]. The setting for this single case study was a Christian church geographically located in a large northeast city. A church was chosen because it is one of the few situations where all six forms of social capital are accessible, and it possesses a horizontal power structure where social capital is available and community concerns are seen as important [18]. Purposive sampling was used to select the research participants in this qualitative case study because each participant needed to provide data to enlighten the researcher about the phenomenon under investigation. 


\section{Data Collection}

Perceptual data was collected through one-on-one semistructured interviews with parents of children ages 10-12 that participated in activities at the church and a focus group was held with adult church leaders who worked directly with the children. Theoretical data was collected from nonparticipant observations at several Sunday church services and meetings. Contextual information was attained by a thorough review of certain church's documents. Contextual data were used to confirm that the selected setting possessed a culture that facilitated that attainment of goals and behaviors that may not be attained without the social systems within the setting. Demographic data was collected from parents of the children by the completion of a personal data form that included age, sex, race, economic status, education, family size, marital status, employment, and neighborhood information.

\section{Findings AND CONClUSIONS FROM DEMOGRAPHIC DATA}

Personal information forms were completed by each parent research participant and collected at the one-on-one informal interviews. The demographic data indicated that the research participants interviewed were largely advanced in age with the mean age at 47 and a median age of 42 . Therefore the parents interviewed were more mature and their responses held value because of their life experiences. In the category of relationship, the majority of parents interviewed were mothers, at $60 \%$.The relationships of fathers and grandparents were included, at 20\%.The majority of perspectives examined were mothers but perspectives of fathers and grandparents created variety in the points of view considered.

The demographics data around marital status revealed that $46 \%$ of the parents were married and $54 \%$ of the families included in the study were single-parent households. The perspectives of both single parent and two parent households were analyzed in this case study. The majority of parents, $47 \%$, possessed an undergraduate college degree or above and that $73 \%$ were employed full time. $33 \%$ earned between $\$ 20,001$ and $\$ 30,000$. Another $33 \%$ of parents earned $\$ 40,000$ or more. In conclusion, the majority of parents were employed full time, possessed college degrees and experienced more economic advantage than disadvantage

The personal information form also asked to assess levels of neighborhood social capital. The results were as follows: Speaking to Neighbors revealed that $73 \%$ of the parents interviewed always or often speaking to their neighbor, which is a Christian value. $66 \%$ shared they would never allow a neighbor to babysit and $73 \%$, declared they would not borrow from a neighbor. $40 \%$ socialized informally with neighbors on the block, while $27 \%$ never socialized informally with neighbors on the block.86\%, never socializing formally with neighbors on the block and $67 \%$ percent shared that sometimes crime is a problem in the neighborhood. Finally, 73\% indicated they never feel secure having their children playing outside without supervision. The demographic data collected around neighborhood social capital revealed that the children of parents interviewed experienced decrease levels of social capital in their neighborhoods.

\section{Analysis of Perceptual Data}

The perceptual data, one-on-one interviews and focus group, was analyzed using a thematic approach that included six phases: a) getting thoroughly acquainted with the data, b) creating codes, c) looking for themes, d) reviewing themes, e) defining and refining, and f) reporting. After completing the above process, consistent themes surfaced that answered the research question, how and why participation in church activities increases the positive social capital required for the academic success of AfricanAmerican children, ages 10-12, who experience decreased levels of positive neighborhood social capital.

\section{Findings And CONClusions of PERCEPtUAl Data}

There were three major consistent themes and four subthemes emerged from analysis of the perceptual data. They were a) Organizational Social Capital, with the subthemes It takes a Village and an Unapologetic Youth Orientation; b) Servant Leaders; c) Positive Attitudes with subthemes Positive Personality Traits and Christian Principles.

\section{A. Major Theme One: Organizational Social Capital}

The church examined in this case study generated and sustained increased levels of organizational social capital for the children that participated in activities through its commitment to collective nurturing and its unapologetic youth orientation. Subtheme 1: It Takes a Village was demonstrated by a common goal of collective nurturing.

On February 16, 2013, the Reverend shared a sermon entitled, "Take Your Hands off My Child" where he discussed the importance of collective nurturing.

If we're going to be the Church of God! If we're going to be the people of God! We have to care about the development of young people. The sign of a culture is seen in how it takes care of its children and what we give to the next generation.

A parent shared in her interview, "It helps so much with the parents bringing them (children) up. Like Pastor says, 'It takes a tribe,' and it does. It takes a whole tribe. It takes a whole family. It takes a whole village."

A grandparent revealed how collective nurturing has been advantageous to her grandson:

When Reverend says, "It takes a village." It does because it's taken all of us! All of my family and all of the church family to bring him up. And I think without all this help, he would be one of those kids you would look at and say what happened to him?

During the focus group, a servant leader expressed how collective nurturing adds more accountability:

I think we provide a higher level of accountability in terms of academics. So I think they are accountable to more than their parents or even their families, but they have a larger community or village that they have to be responsible to.

At a Sunday sermon titled, "We Have to Take Care of 
Our Children", delivered On December 19, 2012, the church Pastor shared:

Go the extra mile. Even if you're not a parent, some of you have been placed in the community to come alongside of parenting. God has brought these children into your life to pick up the pieces. Sometime you come alongside of families. There are children right now that need what your flexible single life has to offer.

Religious organizations are vital to the nurturing of today's child because they possess the ability to create and maintain the social capital needed to properly usher children into adulthood. Collective nurturing creates an environment where closure exists and children understand there is a network of adults working together to help them understand the accepted norms and values of the group. Therefore, when religious organizations understand and dedicate themselves to collective nurturing, children can increase their chances of attaining the norms and values needed for academic success by the reinforcement found in closed networks.

This research also revealed that subtheme 2: Unapologetic Youth Orientation can transform religious organizations into environments that demonstrate their focus by creating a wide-range of activities for participation.

On December 16, 2012, in a sermon entitled, "We Have to Take Care of Our Children," Senior Pastor Reverend Dr. A.W. declared, "We're not wrong in this church to claim that we are unapologetically youth orientated,"

On February 16, 2013, the Pastor delivered a sermon to explain how the church demonstrated its unapologetic commitment to youth:

One of the reasons that we fundamentally said we going to build that field back there and we put down the discussion of expanding the parking is because parking was for the pleasure of some adults. The reality is that field back there facilitates what we been doing with kids all through this community and we wanted to symbolize that we are unapologetically youth orientated.

Unfortunately, participation in activities at religious organizations has reduced over the last 30 to 40 years. Therefore, presenting children with an assortment of choices, rather than traditional choices such as choir members, ushers, and Sunday school will entice and increase participation in activities in religious organizations.

\section{B. Major Theme 2: Servant Leaders}

The second major theme, Servant Leaders, revealed children who experience increased opportunities to acquire positive social capital through interactions with adults, as church leadership, achieve academic success. The church examined in this case study provides children with opportunities to interact with servant leaders who are the adults in charge of the different activities at the organization. Servant leaders are very influential in the academic success of the children because when children have opportunities to interact with adults outside of their family who hold them accountable, they have higher standards to abide by because of the expectations beyond the immediate family. This higher standard increases academic accountability, expectations, and success. Religious organizations that incorporate adults to serve as leaders of activities provide the children with more accountability that leads to academic success and a reduction in America's achievement gap.

Parents shared how and why interactions with servant leaders help with academic success:

I mean you could be here and the servant leader pretty much gets familiar with all the students and have rapport. You know, just talking to them. I do believe that having an adult around, a constant present person that's in your face makes you accountable.

One important responsibility of Servant Leaders was shared during the focus group:

So they see that we care. We call them. It's a responsibility to call the family. We ask the mom and dad how the kids are doing. And they'll give us a report then once the kid comes to us, then it's our responsibility to take that information and do something with it.

Religious organizations that incorporate adults to serve as leaders of activities provide the children with more academic accountability and access to educational information while being encouraged which leads to educational success.

\section{Major Theme 3: Positive Attitudes}

The third major theme, Positive Attitude, found that positive attitudes around educational success are a result of two things: Positive Personality Traits and Christian Principles. These two subthemes make it possible for children to form the positive attitudes needed to achieve in school. Children that participated in activities at the church cultivated self-esteem and confidence from the support and accomplishments they experienced. Self-discipline and responsibility were developed from the activities designed to encourage self-control and accountability.

One father shared how a specific ministry helped with his daughter's self-esteem:

From the moment she started participating, her whole outlook and the way she is totally changed, absolutely. She's no longer the little shy girl. The teacher said she's the one that speaks up in class. Now, she's the confident one.

A grandparent shared how learning self-discipline helped her grandchild, "I think participating in church gives the children more self-discipline or self-structure for themselves, not just in school, but anywhere they go."

During the focus group, Servant Leader's discussed how participation develops the responsibility needed improve positive attitudes about academic success, "You need to be able to work with others and take responsibility for your own actions."

Self-esteem, self-confidence, self-discipline, and responsibility are some of the positive personality traits developed in the children who participate in activities at the case study church. These positive personality traits contribute to the development of the positive attitude needed to achieve academic success.

Christian principles, as a point of view, helped develop the positive attitude children need to succeed. Christian principles include being involved in the events, such as prayer, reading and reciting scripture, which produce an inner self that pushes beyond difficulties to achieve the academic goals that lead to success. Therefore, activities that children participate in at religious organizations must include the sharing of Christian principles and the actions that reinforce these principles. 
In the focus group, Servant Leader's shared the importance of prayer and scripture in the youth ministries:

They come with attitudes, you know, and I always tell them, it's a lot going on school and things like that. But don't let it define you. The main thing they do before they kick and jump is pray, and learn scripture.

Another parent discussed how Christian principles encourage the youth that participate in activities at the church:

They also are given the opportunity to be successful in knowing who Jesus Christ is and who they belong to. They are made aware that it's okay to be different. It's okay to study. It's okay to prepare for our SATs because all those opportunities are there at the church for them.

The positive personality traits developed in the children who participate in activities at the church help create the positive attitude around the significance of succeeding academically. The Christian principles taught and reinforced at the case study church nurture the positive point of view needed to develop positive attitudes around the importance of academic success in school.

\section{IMPLICATIONS FOR PRACTICE}

The findings of this research project hold many implications for practice in neighborhood churches in America. Neighborhood churches must prepare themselves to come alongside of public school education and aid in the elimination of its unceasing achievement gap. AfricanAmerican neighborhood churches, in particular, can greatly assist in the reduction of America's achievement gap by providing more opportunities for children who experience reduced social capital to acquire the social capital needed for academic success.

Neighborhood churches that desire to support the academic success of their children must

- make children in the local church and the larger community the priority in the organization;

- demonstrate that children are a priority through collective nurturing;

- organize adults to serve as leaders to children in activities and mentor them by sharing information, reinforcing norms and values, and increasing academic accountability;

- create a plethora of unique activities that attract participation and develop positive personality traits, such as self-esteem, confidence, self-discipline, and responsibility; and.

- use Christian principles and its actions, such as prayer and reading and reciting scripture, to create a positive point of view

\section{RECOMMENDATIONS}

Future research is recommended in diverse settings such as civic or other social organizations in the communities that serve children. Action research projects are also recommended to establish best practices for youth programming at neighborhood churches and help churches examine their present situation, identify any limitations, and work cooperatively to move forward. Finally, future research recommendations must include interviewing or surveying children to gain their perspective on the impact positive social capital has on academic success.

\section{ACKNOWLEDGMENTS}

First, I would like to acknowledge God for the energy, motivation, and endurance to complete this research project. I would also like to acknowledge family and friends who supported and encouraged during my journey. Finally, I would like to acknowledge the research participants who generously shared their experiences and time.

\section{REFERENCES}

[1] W. J. Wilson, "Inner-city dislocation," Society, pp. 270-277, January/February 1998.

[2] W. J. Wilson, The Truly Disadvantaged: The Inner City, the Underclass, and Public Policy, Chicago, IL: University of Chicago Press, 1987.

[3] B. L. McCombs, "Reducing the achievement gap," Society, vol. 37, no. 5, pp. 29-36, 2000.

[4] L. J. Hanifan, "The rural school community center," The Annuals of the American Academy of Political and Social Science, vol. 67, no. 1, pp. 1130-1138, 1916.

[5] P. Bourdieu, "The forms of social capital," Handbook of theory and Research for the Sociology of Education, pp. 241-258, 1986.

[6] J. S. Coleman, Foundations of Social Theory, Cambridge, MA: Harvard University Press, 1990.

[7] R. D. Putnam, Bowling Alone: The Collapse and Revival of American Community, New York, NY: Simon \& Schuster, 2000.

[8] R. D. Putnam and L. M. Feldstein, Better Together: Restoring the American Community, New York, NY: Simon \& Schuster, 2007.

[9] K. Beyerlein and J. R. Hipp, "Social capital, too much of a good thing? American religious traditions and community crime," Social Forces, vol.8, no. 2, pp. 995-1013, 2005.

[10] I. Kawachi, B. P. Kennedy et al., "Social capital, income, inequality \& mortality," American Journal of Public Health, vol. 87, no. 9, pp. 169-200, 1999.

[11] N. Lin, "Social networks and status attainment," Annual Review of Sociology, vol. 25, no. 1, pp. 467-487, 1999.

[12] J. A. Coleman, "Religious social capital: It's nature, social location, and limits," in Religion as Social Capital: Producing the common Good, C. Smidt, Ed., Waco, TX: Baylor University Press, 2003, pp. 33-47.

[13] F. Harris, "Ties that bind and flourish: Religion as social capital in African-American politics," in Religion as Social Capital: Producing the Common Good, C. Smidt, Ed., Waco, TX: Baylor University Press, 2003, pp. 121-137.

[14] J. A. Coleman, "Religious social capital: It's nature, social location, and limits," in Religion as Social Capital: Producing the Common Good, C. Smidt, Ed., Waco, TX: Baylor University Press, 2003, pp. 33-47.

[15] R. W. Gaines, "Looking back, moving forward: How the civic rights era church can guide the modern Black church in improving black student achievement," The Journal of Negro Education, vol. 79, no. 3, pp. 366-379. 2010 .

[16] R. J. Taylor and L. M. Chatters, "Importance of religion and spirituality in the lives of African Americans, Caribbean Blacks, and Non-Hispanic Whites," The Journal of Negro Education, vol. 79, no.3, pp. 28-294, 2010.

[17] P. Baxter and S. Jack. "Qualitative case study methodology: Study design and implementation for novice researcher," The Qualitative Report, vol. 13, no. 4, pp. 544-559, 2008.

[18] C. Smith, "Theorizing religious effects among American adolescents," Journal for the Scientific Study of Religion, vol. 42, no. 1, pp. 17-30, 2003.

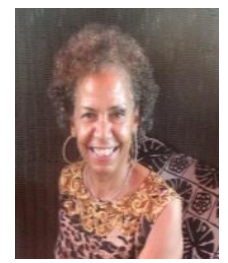

Sylvia D. Briscoe was born in Philadelphia, PA., where she attended and graduated from its public school system. She earned a Ph.D. in Organizational Leadership from Argosy University's School of Business in Phoenix, Arizona in October, 2013. She received her masters of science degree in education from Antioch University located in Yellow Springs Ohio in January, 1979. Dr. Briscoe attended City 
College of New York located in New York, New York where she received her Bachelor of Science in Education in September, 1974. Dr. Briscoe's major field of study is social capital and academic success in children.

Currently she works as a consultant for Neighborhoods United Against Drugs and other non-profit organizations located in Philadelphia, PA. While working with the School District of Philadelphia, she served as Dean of Students, Lead Teacher, Junior Academy Mathematics Curriculum Coordinator, and Mathematics Fellow for Urban Systemic Program. At the Lafayette School Corporation, in Lafayette, IN, she assisted in writing and implementing the pilot program, Slice of Tomorrow, aimed to create lifelong learners of elementary students through multi-age grouping, team teaching techniques and technology in the classroom. Some of her key accomplishments are the development and implementation of a successful Saturday School Program for At-Risk Students, Coordinated and collaborated with TOVA: Artistic Projects for Social Change to develop
Peacemakers program to promote positive decision making, attended C.A.T.C.H Program at Fruedenthal Institute in Utrecht, Holland that focused on Inquiry Learning and using assessment to guide instruction and lead and developed workshops for 300 teachers to increase the level of mathematics instruction using inquiry learning. Dr. Briscoe continues her research around social capital and academic success of children.

Dr. Briscoe is a member of the National Society of Collegiate Scholars. She served as member of Indiana School Technology Enterprise Council, elected as the first female President of Lafayette, IN. Chapter of the N.A.A.C.P, and served on the board of the Hanna Community Council Her research was presented and published at the conference titled: Crisis in Education: From Problems to Solutions sponsored by the AfricanAmerican Council for Educational Justice. 